\title{
Job Satisfaction among Nursing Faculties of Chitwan District
}

\author{
Rojina Baral, ${ }^{1}$ Rabina Bhatta ${ }^{2}$ \\ ${ }^{1}$ Department of Nursing, College of Medical Sciences and Teaching Hospital, Chitwan, Nepal, ${ }^{2}$ Department of Nursing, \\ Shree Medical \& Technical College, Chitwan, Nepal.
}

\begin{abstract}
Background: A healthier and harmonious working environment, ample of opportunity to grab in, considerable payable amount, a sound professional growth and many others are the major backbone for a satisfaction in the work. Nursing is a profession who has a long working hours, plenty of paper work, and a lot of pressure to make a naive practice in a real environment. Thus, this study focuses on job satisfaction among nursing faculties. Materials and Methods: A cross-sectional analytical study was conducted among 62 nursing faculties. involved in teaching graduate nursing students. All the nursing faculties who are involved in teaching graduate nursing students were included in the study. Sample were collected from all five nursing college of chitwan district regulating graduate nursing program. Census method was used to collect the data. Job satisfaction survey was used to collect the data. The data gathered was analyzed using both descriptive and inferential statistics in SPSS software. Results: Among total of 62 participants, more than three fourth $79 \%$ of the participants were ambivalent (neither satisfied nor dissatisfied) whereas, $21 \%$ were dissatisfied in their jobs. Also, age $(\mathrm{p}=0.003) /$ among all the socio demographic variable, internet facility $(\mathrm{p}=0.044)$ and increment in grade system $(\mathrm{p}=0.004)$ among the variable regarding organizational climate was found to be statistically significant with the job satisfaction. Conclusions: A healthier working environment with certain aspects for the personal and professional growth is vital to improve the job satisfaction thus empowering the nursing faculties for their best performances.
\end{abstract}

Keywords: chitwan; nursing; satisfaction.

\section{INTRODUCTION}

A sense of satisfaction and accomplishment in a job is most crucial to improve the productivity of an individual and a success outcome. Job satisfaction is the key ingredient the leads to recognition, income, promotion, and the achievement of other goals that lead to a feeling of fulfilment. ${ }^{1}$ Among various profession, nursing profession is one among where an individual is threatened by heavy workload, multiple role expectations, insufficient time, lack of mentoring, and lack of collegial support, ${ }^{2}$ which leads to decreased job performance, negative attitudes toward work, lack of motivation, and eventually detachment from the job. ${ }^{3}$

Job satisfaction among nurses is a great concern throughout the world but the satisfaction of nurse teachers has received less attention. ${ }^{4}$ The nurse educator role is essential to the ongoing development of the profession and the ability of the discipline to meet society's needs for quality nursing care. Lower level of job satisfaction tend to lower the quality of nursing teaching and learning. ${ }^{5}$ Therefore, this study aims to assess the level of job satisfaction among nursing teachers..

\section{MATERIALS AND METHODS}

A cross-sectional analytical study was conducted among 62 nursing teachers involved in teaching graduate nursing students of Chitwan district. Ethical approval was received from the Institutional Review Board of College of Medical Sciences and permission from all five nursing college was obtained. Written consent was signed from all study participants. Institutional Census method was used for collecting the sample. Nursing faculties who were involved in teaching graduate nurses; bachelor degree with at least 5 years of experience and masters degree with at least 1 years of experience were included in the study. Semi-structured questionnaire regarding socio-demographic and organizational climate was formulated and a standardized tool; Job satisfaction survey was used to collect the data. ${ }^{6}$ Data was entered in Excel and

Correspondence: Rojina Baral, Department of Nursing, College of Medical Sciences, Bharatpur, Chitwan, Nepal. Email: rojina.baral@gmail.com. Phone: +977-9845817996. DOI: 10.3126/jcmsn.v14i4.22559. Article received: 2018-10-26. Article accepted: 2018-12-10. 
SPSS version 20 was used for statistical analysis. Descriptive statistics was used to analyze sociodemographic and organizational climate variable, whereas statistical test was used to find out the association between different variables and job satisfaction.

\section{RESULTS}

Among total of 62 participants, more than half belong to age group 30-40, where majority were female and $6.5 \%$ were male. Three fourth of the

\begin{tabular}{|c|c|c|}
\hline \multicolumn{3}{|c|}{$\begin{array}{l}\text { Table 1. Respondents' } \\
\text { characteristics. }\end{array}$} \\
\hline Characteristics & Frequency & Percentage \\
\hline \multicolumn{3}{|l|}{ Age } \\
\hline$<30$ & 13 & 21.0 \\
\hline $30-40$ & 36 & 58.1 \\
\hline $40-50$ & 6 & 9.7 \\
\hline$>50$ & 7 & 11.3 \\
\hline \multicolumn{3}{|l|}{ Gender } \\
\hline Male & 4 & 6.5 \\
\hline Female & 58 & 93.5 \\
\hline \multicolumn{3}{|l|}{ Education } \\
\hline $\mathrm{BN}$ & 3 & 4.8 \\
\hline Bsc & 1 & 1.6 \\
\hline $\mathrm{MN}$ & 44 & 71.0 \\
\hline Msc & 12 & 19.4 \\
\hline Ph.D in nursing & 2 & 3.2 \\
\hline \multicolumn{3}{|l|}{ Designation } \\
\hline Assistant lecturer & 1 & 1.6 \\
\hline Lecturer & 44 & 71.0 \\
\hline Assistant professor & 6 & 9.7 \\
\hline Associate professor & 11 & 17.7 \\
\hline \multicolumn{3}{|l|}{$\begin{array}{c}\text { Year of teaching ex- } \\
\text { perience (in completed } \\
\text { years) }\end{array}$} \\
\hline 1 year & 9 & 14.5 \\
\hline 2 years & 7 & 11.3 \\
\hline 3 years & 4 & 6.5 \\
\hline more than 3 years & 42 & 67.7 \\
\hline \multicolumn{3}{|l|}{$\begin{array}{l}\text { Number of years of } \\
\text { teaching }\end{array}$} \\
\hline 1 years & 14 & 22.6 \\
\hline 2 years & 7 & 11.3 \\
\hline 3 years & 6 & 9.7 \\
\hline more than 3 years & 35 & 56.5 \\
\hline \multicolumn{3}{|l|}{ Tenure status } \\
\hline Contract & 28 & 45.2 \\
\hline Temporary & 16 & 25.8 \\
\hline Permanent & 18 & 29.0 \\
\hline \multicolumn{3}{|l|}{ Total Hour of classes } \\
\hline$<200$ & 60 & 96.8 \\
\hline$>200$ & 2 & 3.2 \\
\hline \multicolumn{3}{|l|}{ Type of Institute } \\
\hline Government & 8 & 12.9 \\
\hline Semi government & 2 & 3.2 \\
\hline Private & 52 & 83.9 \\
\hline
\end{tabular}

participants had completed post graduate of nursing, and majority $67.7 \%$ had more than 3 years of experience. Almost $50 \%$ of the participants were on tenure of contract basis working and more than $80 \%$ were working in private institution (Table 1). The organization climate in terms of personal involvement, opportunity for education, internet facility, increment in grade system, provision of provident fund, payment of supervision has been summarized in Table 2.

\begin{tabular}{|l|c|c|}
\hline \multicolumn{3}{|c|}{ Table 2. Organizational climate variables. } \\
\hline Characteristics & Frequency & Percentage \\
\hline Professional involvement & & \\
\hline Yes & 45 & 72.6 \\
\hline No & 17 & 27.4 \\
\hline $\begin{array}{l}\text { Opportunity for educa- } \\
\text { tion }\end{array}$ & & \\
\hline Yes & 16 & 25.8 \\
\hline No & 46 & 74.2 \\
\hline Internet facility & & \\
\hline Yes & 54 & 87.1 \\
\hline No & 8 & 12.9 \\
\hline $\begin{array}{l}\text { Increment in grade sys- } \\
\text { tem }\end{array}$ & & \\
\hline Yes & 47 & 75.8 \\
\hline No & 15 & 24.2 \\
\hline Provident fund & & \\
\hline Yes & 41 & 66.1 \\
\hline No & 21 & 33.9 \\
\hline Supervise on research & & \\
\hline Yes & 56 & 90.3 \\
\hline No & & \\
\hline $\begin{array}{l}\text { Payment for research } \\
\text { supervision }\end{array}$ & & \\
\hline Yes & & \\
\hline No & & \\
\hline & & \\
\hline
\end{tabular}

Seventy nine percent of the participant are neither satisfied nor dissatisfied where as 21 percent are dissatisfied with the job (Figure 1). Age group in demographic variables (Table 3 ) and facilities like

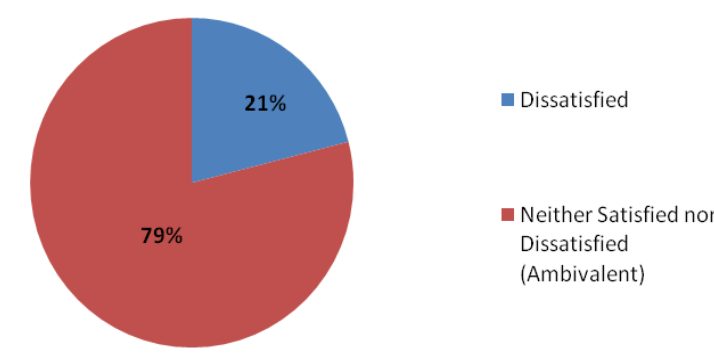

Figure 1. Job satisfaction among nurses. 
availability of internet and increment in grade was found to be significantly associated with the job satisfaction ( Table 4).

\begin{tabular}{|c|c|c|c|c|}
\hline \multicolumn{5}{|c|}{$\begin{array}{l}\text { Table 3. Association among Level of Job satisfac- } \\
\text { tion among nursing teachers and Socio- } \\
\text { Demographic Variables. }\end{array}$} \\
\hline $\begin{array}{l}\text { Characteris- } \\
\text { tics }\end{array}$ & Ambivalent & $\begin{array}{l}\text { Dissatis- } \\
\text { fied }\end{array}$ & \multirow[t]{2}{*}{$\begin{array}{l}\text { Chi- } \\
\text { square }\end{array}$} & $\begin{array}{l}\text { P- } \\
\text { value }\end{array}$ \\
\hline Age & & & & \multirow{5}{*}{.031} \\
\hline$<30$ & $13(100.0 \%)$ & & \multirow{4}{*}{8.845} & \\
\hline $30-40$ & $28(77.8 \%)$ & $8(22.2 \%)$ & & \\
\hline $40-50$ & $3(50.0 \%)$ & $3(50.0 \%)$ & & \\
\hline$>50$ & $5(71.4 \%)$ & $2(28.6 \%)$ & & \\
\hline
\end{tabular}

Table 4. Association among Level of Job satisfaction among nursing teachers and Organizational Variables.

\begin{tabular}{|c|c|c|c|c|}
\hline Characteristics & Ambivalent & $\begin{array}{l}\text { Dissatis- } \\
\text { fied }\end{array}$ & $\begin{array}{l}\text { Chi- } \\
\text { square }\end{array}$ & $\begin{array}{l}\text { P- } \\
\text { value }\end{array}$ \\
\hline \multicolumn{5}{|l|}{ Internet Facility } \\
\hline Yes & $41(75.9 \%)$ & $\begin{array}{l}13 \\
(24.1 \%)\end{array}$ & \multirow[t]{3}{*}{4.069} & \multirow[t]{3}{*}{.044} \\
\hline No & $8(100.0 \%)$ & 0 & & \\
\hline $\begin{array}{l}\text { Increment in } \\
\text { grade system }\end{array}$ & & & & \\
\hline Yes & $34(72.3 \%)$ & $\begin{array}{l}13 \\
(27.7 \%)\end{array}$ & \multirow[t]{2}{*}{8.245} & \multirow[t]{2}{*}{.004} \\
\hline No & $15(100.0 \%)$ & 0 & & \\
\hline
\end{tabular}

\section{DISCUSSION}

Every individual demands to be satisfied with the job, but the relationship of job dissatisfaction and satisfaction depends upon what an individual expects and obtains from his job. ${ }^{7}$ A nurses hold many responsibilities under a hat, where nurse educator is one among the most challenging job for a nurse. ${ }^{8}$ Thus, dissatisfaction of nursing faculties may threaten the ecosystem integrity of work place which is reflected from one's behaviour. ${ }^{9}$

The findings of the present study indicated that $93.5 \%$ of participants were female. It is very obvious in our context where nursing is regarded as a female dominant profession. This finding is consistent with the findings of other Asian countries like Malaysia, ${ }^{10}$ Thailand ${ }^{11}$ where 98.6 $\%, 100 \%$ were female respectively. Three fourth of the participants had pursued post graduate degree, which depicts that majority of the postgraduate nursing are involved in teaching graduate nurses. Considering the tenure status, very minimum $(29 \%)$ participants are in permanent service; this may be due to the maximum involvement of nurses in private sectors. Regarding the organizational climate, majority of the participants were satisfied with having the facilities like increment in the grade system, provident fund, availability of the internet, supervision of the research, professional involvement but only few $25.8 \%$ only have the opportunity for the education. Many studies conclude that Organizational climate has been a major factor for job satisfaction, 9,12 where as some studies contradict the findings concluding that organizational climate has a low predictive or a negligible relationship with Job satisfaction. ${ }^{8,13}$

The main findings of the study indicates that 79 percent of the participant are neither satisfied nor dissatisfied where as 21 percent are dissatisfied with the job. This finding is comparable with the study done in Malaysia, which demonstrates a moderate level of job satisfaction. ${ }^{9}$ Whereas, many studies conducted in India, ${ }^{14}$ Australia ${ }^{15}$ and different parts of United States: Florida, ${ }^{16}$ California ${ }^{17}$ contradict the findings illustrating that nurses are completely satisfied and passionate with their job. The findings may vary due to different socio-economic status in developed countries.

\section{CONCLUSION}

Though job satisfaction is an individualized subjective feeling, the result may not be static; but the factor hindering the job satisfaction among nursing faculties should be given attention and further opportunities for the professional growth and employee expectation need to be addressed, so that they can actively involve in the development of healthcare services and education.

\section{REFERENCES}

1. Kaliski, B.S. (2007). Encyclopedia of Business and Finance, Second Edition, Thompsan Gale, Detroit, p. 446 [Link]

2. Gazza, E. A. (2009) The experience of being a full-time nursing faculty in a baccalaureate nursing education program. Journal of Professional Nursing, 25(4), 218-226. Doi: 10.1016 [pubmed]

3. Candela L, Gutierrez A, Keating S. A national survey examining the professional work life of today's nursing faculty. 2013 Aug; 33(8):8539. [pubmed]
4. Gui L, Barriball 'KL, While AE. Job satisfaction of nurse teachers: a literature review. Part I: Measurement, Levels and components. 2009 Jul;29(5):469-76. doi: 10.1016/j.nedt.2008.11.002 [pubmed]

5. NLN Vision : Transforming Research in Nursing Education. A living documents for the National league for Nursing. NLN Board of Governors. November 2012 [Link]

6. Neha Batura, Jolene Skordis, Rita Thapa, Regina Basnyat, Joanna Morrison. Is the job satisfaction survey a good tool to measure job satisfaction amongst heath workers in Nepal. 
Bio Med Centra. 2016; 16: 308. [pubmed]

7. Natarajan, R., (2001) A study on School Organizational climate and Job Satisfaction of Teachers. Journal of Educational Research and Extension pp: 36-43 [Link]

8. Denise K Gormley. Factors affecting job satisfaction in nurse faculty: a Meta analysis. Journal of Nursing Education 42(4):174-8 May 2003. [pubmed]

9. Moody NB. Nurse faculty job satisfaction: a nationa survey. 1996 sept- oct; 12(5):277-88. PMID:8871693 [pubmed]

10. Che Chong Chin, Alsion Beauchamp \& Kenneth Sellick. Job Satisfaction of Nurse Lecturers In Malaysia. The Malaysian Journal Of Nursing. Vol 4(2) oct 2012. [Link]

11. Fuanglada Sethawat. Job satisfaction among nursing faculty in Royal Thai Air force Nursing College. 1993, 646. [Link]

12. Catherine E. Chung, Susan Kowalski. Job Stress, Mentoring, Psychological Empowerment, And Job Satisfaction Among
Nursing Faculty. Journal of Nursing Education. 2012;51(7):381-388, July1, 2012 [pubmed]

13. Carol E Snarr, Pamela C Krochalk. Job Satisfaction and Organizational Characterstics: Results of A Nation Wide Survey of Baccalaureate Nursing Faculty In United States. 24(2) August 1996, 405-412. [pubmed]

14. Saini S, Singh C. Job satisfaction among nursing personnel. Nurs Midwifery Res [Internet]. 2005;1(2):64-9. [link]

15. Holland P, Allen B, Cooper B. What nurses want: analysis of the first national survey on nurses' attitudes to work and work conditions in Australia. Monash University; 2012. [link]

16. Kathleen A. Lane, Joni Esser, Betty Holte, Marie Anne Mc Cusker. A Study of Nurse Faculty Job Satisfaction in Community College in Florida. 5(1) Jan 2010, 16-26. [link]

17. Wild P. Nurse Practitioner's Characteristics and Job Satisfaction. J Am Acad Nurse Pract [Internet]. 2006;18:544-9. [pubmed]

Citation: Baral R, Bhatta R. Job Satisfaction among Nursing Faculties of Chitwan District. JCMS Nepal. 2018;14(4):221-4. 